\title{
Knowledge, attitudes and practices survey among health care workers and tuberculosis patients in Iraq
}

D.S. Hashim, ${ }^{1}$ W. Al Kubaisy ${ }^{2}$ and A. Al Dulayme ${ }^{3}$

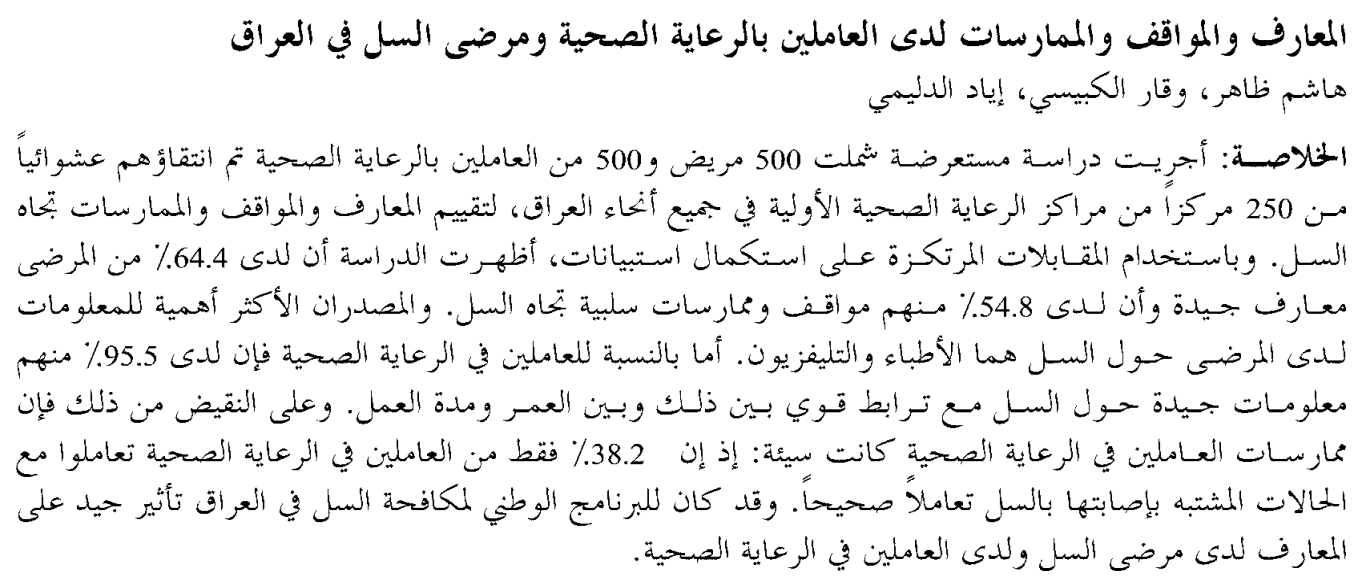

ABSTRACT A cross-sectional study was made of 500 patients and 500 health care workers randomly selected from 250 primary health care centres throughout Iraq to evaluate knowledge, attitudes and practices towards tuberculosis (TB). Using structured questionnaire interviews, the study showed $64.4 \%$ of patients had good knowledge, while 54.8\% had negative attitudes and practices towards TB. The 2 most important sources of patient information about TB were physicians and television. Of health care workers, $95.5 \%$ had good knowledge about TB and this was significantly associated with age and job duration. By contrast, health care workers' practice was poor: only $38.2 \%$ handled suspected TB cases correctly. The national TB programme in Iraq has had a good impact on knowledge of TB patients and health care workers.

Enquête sur les connaissances, attitudes et pratiques parmi les agents de santé et les patients tuberculeux en Iraq

RESUME Une étude transversale a été réalisée auprès de 500 patients et de 500 agents de santé choisis au hasard dans 250 centres de soins de santé primaires dans l'ensemble de l'Iraq afin d'évaluer les connaissances, les attitudes et les pratiques concernant la tuberculose. A travers des entretiens par questionnaire structuré, l'étude a montré que $64,4 \%$ des patients avaient de bonnes connaissances, tandis que $54,8 \%$ avaient des attitudes et des pratiques négatives. Les médecins et la télévision étaient les deux sources d'information sur la tuberculose les plus importantes pour les patients. Parmi les agents de santé, $95,5 \%$ avaient de bonnes connaissances concernant la tuberculose et il y avait une association significative avec l'âge et la durée de l'emploi. En revanche, les pratiques des agents de santé étaient peu satisfaisantes : seuls $38,2 \%$ traitaient correctement les cas suspects de tuberculose. Le programme national de lutte antituberculeuse en Iraq a eu un bon impact sur les connaissances des patients tuberculeux et des agents de santé.

${ }^{1}$ National Tuberculosis Programme Manager, Ministry of Health, Baghdad, Iraq.

${ }^{2}$ Department of Community Medicine, Saddam College of Medicine, Baghdad, Iraq.

${ }^{3}$ Chest and Respiratory Diseases Institute, Baghdad, Iraq.

المجلة الصحية لشرق المتوسط، منظمة الصحة العالمية، المجلد التاسع، العدد ع، ب... 


\section{Introduction}

Iraq has a high burden of tuberculosis (TB) and ranks 44th worldwide among countries with a high TB burden and 7th among the countries of the Eastern Mediterranean Region. The estimated incidence of all TB cases based on a total population of 22.9 million was at least 135 per 100000 in the year 2001 [1,2]. In 2001 a total of 10478 TB cases were notified, which corresponds to a case notification rate of 48 per 100000 , and means that Iraq can be categorized as a country with a medium level notification rate $[3,4]$.

The Iraqi national TB programme has adopted the directly observed treatment short-course (DOTS) strategy since 1998 and by October 2000 the strategy covered all governorates.

In most of the TB control efforts, including those undertaken in Iraq, clinical aspects of the diseases receive more attention than the human aspects. There is a growing realization that the psychosocial suffering experienced by TB patients and their families needs more attention [5,6]. Therefore it has become clear that problems in case detection and case-holding are not solved by a clinical approach alone, but there is a need for community participation to support the efforts of health care workers, while giving special attention to the gender aspects of TB. As community involvement is crucial for any successful TB control programme, several studies have been performed to identify knowledge, perceptions and practices of the population regarding the occurrence, transmission, treatment and control of TB $[7,8]$.

On the other hand, inefficient case-finding is an important obstacle to successful control of TB. Patients who are involved in several different health care encounters may account for delayed case-finding. Case studies illustrate the rationale for health-seeking and explain delayed initiation of appropriate approaches to health communication for improved control of TB. Certain reports also suggest that improved interpersonal skills of health centre staff and coordination between private doctors and health centres may substantially improve services for TB patients $[9,10]$.

A considerable proportion of patients do not know about the mode of spread of the disease [11]. Awareness about investigations such as chest X-ray is significantly higher than that of sputum examination. There is a high degree of knowledge regarding the harmful sequelae of inadequate and incomplete treatment but inadequate knowledge about the duration of treatment. These studies emphasized the need for health education to create better awareness of these important aspects of TB diagnosis, treatment and control.

Research in many parts of the world has shown that improved communication between health care providers and TB patients and their families contributes to better therapeutic outcomes, and this can also be applied to case detection. Decentralizing of DOTS to health centres with supervision by health care workers or by guardians in the community during the intensive phase is associated with satisfactory treatment outcomes $[11,12]$. No previous studies have been performed to evaluate the knowledge, attitudes and practices of TB patients and their health care workers after DOTS implementation in Iraq. This research, therefore aims to identify the factors preventing a better understanding of TB as a social and medical problem, with the ultimate goal of improving the quality of case detection and therapeutic outcomes for TB patients in Iraq.

المجلة الصحية لشرق المتوسط، منظمة الصحة العالمية، المجلد التاسع، العدد ع، بr..r 


\section{Methods}

The public health service in Iraq has 975 primary health care centres (PHCs) distributed over 15 governorates, each including at least 4-5 health care workers who, in addition to their normal work, are trained annually to manage any case of TB according to the DOTS programme.

A cross-sectional study was carried out during a 1-year period (November 2001 to November 2002) whereby a random sample of 500 TB patients and 500 health care workers were enrolled from randomly selected PHCs. Both patients and their health care workers were interviewed according to a pretested questionnaire about their knowledge, attitudes and practices concerning TB.

\section{Sample}

Two sampling frames of urban and rural PHCs were developed, with the number of selected urban or rural PHCs proportionate to the total number of PHCs in that frame. The PHCs were selected using a systematic sampling technique and a total of 250 were finally selected out of 975 PHCs (404 rural 541 urban) distributed over all Iraqi governorates. With a prevalence for TB in Iraq of $0.13 \%$ in 2000 [3], at a $95 \%$ confidence interval and allowing an error of $0.5 \%$, the least reliable sample size was 364 patients. Two (2) smear-positive TB patients aged 15 years or over and 2 health care workers, 1 of them the drug provider, were selected from each PHC on 2 fixed days per week. All study subjects consented to be interviewed, giving a response rate of $100 \%$. Patients younger than 15 years old and those with mental disability or with speech or hearing problems were excluded from the study.

\section{Data collection}

Two types of questionnaire form were designed, 1 for health care workers and 1 for TB patients, which were filled by face-toface interview after obtaining informed consent from the participant.

The reliability of the questionnaires was tested on 30 patients and 30 health care workers who were interviewed twice by the same interviewer (for inter-rater variation) and by another interviewer (for intrarater variation). Kappa test results ranged from $0.95-1$ to $0.96-1$ for both types of variation in the patients' and health care workers' questionnaire respectively.

The patients' questionnaire consisted of 22 questions and included information on the sociodemographic characteristics of patients: crowding index, distance from health centres, smoking history and clinical features. The knowledge of patients about TB was assessed for the following topics: modes of transmission; severity of the disease; its curability; consequences of interrupting treatment; and sources of information. The attitudes and practices of patients were also investigated with questions about: causes of delay in seeking health care; the health facility visited to get initial care; investigating family contacts once the TB diagnosis had been confirmed; and who advised them to seek care.

The health care workers' questionnaire consisted of 14 questions and included information on the sociodemographic characteristics of the health worker and questions assessing their knowledge, attitudes, and practices regarding TB as follows: etiology; transmission; symptoms; risk assessment; treatment of TB; investigation of TB suspects; tracing of contacts; anti-TB therapy regimens under the DOTS strategy; and interactions with patients. 
Every question was rated and a total score was obtained for patients' and health care workers' knowledge, attitudes or practices. Those with a total score equal or below the median were classified as having poor knowledge while those above the median were considered to have good knowledge.

\section{Statistical analysis}

Descriptive statistics were presented to evaluate the knowledge of patients and health workers regarding TB. The chisquared test was used to compare different proportions and to test the association between good knowledge, attitudes and practices and different sociodemographic, clinical and other variables.

The 5\% level of significance was used as the cut-off for statistical significance and all tests were 2-sided. The analyses were conducted using the statistical packages Epi-Info, version 6.04 (Centers for Disease Control and Prevention, Atlanta, Georgia) and SPSS, version 9 (SPSS Inc., Chicago, Illinois).

\section{Results}

\section{Patients}

With respect to knowledge about TB, 322 out of 500 patients (64.4\%) scored 'good' on their overall level of knowledge about the disease.

\section{Sociodemographic characteristics}

The sociodemographic and health characteristics of all patients and those with good knowledge are reported in Table 1 . There were 333 (66.6\%) males and 167 (33.4\%) females, with no significant difference in the proportions with good knowledge (65.8\% and $61.7 \%$ respectively). The mean age of patients was $36.4 \pm 16.4$ years, ranging from 15 to 70 years. Knowl- edge about TB was significantly higher among patients with older age $(P<0.01)$, higher levels of education $(P<0.001)$ and lower levels of household crowding $(P<$ 0.001). Women employed outside the house were more likely to have good knowledge about TB than those working as housewives (90.4\% versus $57.5 \%)(P=$ 0.004).

A significantly higher proportion of smear-negative patients had good knowledge than smear-positive patients $(P<$ 0.05); however, no association between knowledge and X-ray status were seen.

\section{Presentation of TB}

The majority of TB patients (83.8\%) presented with cough, followed by fever (56.6\%), chest pain (44.4\%) or haemoptysis $(30.2 \%)$. There was a significant association between good knowledge and presenting with cough $(P=0.005)$, fever, $(P=0.005)$ and haemoptysis $(P<0.001)$ (Table 2). By contrast, there was no association between knowledge and chest pain, loss of weight or pallor (Table 2).

\section{Knowledge about TB}

Regarding patients' knowledge about TB, Table 3 shows that $80.2 \%$ knew it was a highly infectious disease and $90.0 \%$ that TB is curable. TB is transmitted by cough according to $61.0 \%$, while $55.4 \%$ mentioned breathing and the rest mentioned spitting, kissing, touching or food (26.8\%, $20.8 \%$, 20.6\%, 15.2\% respectively). The source of information about TB was the physician for $27.5 \%$ of patients, the mass media (mainly television) for $23.2 \%$ and 'life experience' for $16.0 \%$.

Concerning the consequences of interrupted treatment, $59.0 \%$ of patients believed that TB would never be cured and $27.0 \%$ that it would result in death. A few (3.6\%) believed that patients develop drug

المجلة الصحية لشرق المتوسط، منظمة الصحة العالمية، المجلد التاسع، العدد ع، بr.ب 
Table 1 Sociodemographic and health characteristics of all tuberculosis (TB) patients and the 322 with good knowledge scores about the disease

\begin{tabular}{|c|c|c|c|c|c|}
\hline \multirow{2}{*}{$\begin{array}{l}\text { Demographicl } \\
\text { health variable } \\
\text { Age (years) }\end{array}$} & \multicolumn{2}{|c|}{$\begin{array}{l}\text { Total sample } \\
\quad(n=500)\end{array}$} & \multicolumn{2}{|c|}{$\begin{array}{c}\text { Good } \\
\text { knowledge }\end{array}$} & Significance \\
\hline & & & & & $\chi^{2}=16.7, \mathrm{df}=6, P<0.01$ \\
\hline $15-19$ & 55 & $(11.0)$ & 37 & 67.3 & \\
\hline $20-29$ & 159 & (31.8) & 112 & 70.4 & \\
\hline 30-39 & 101 & $(20.2)$ & 66 & 65.3 & \\
\hline $40-49$ & 64 & $(12.8)$ & 40 & 62.5 & \\
\hline $50-59$ & 53 & $(10.6)$ & 31 & 58.5 & \\
\hline $60-69$ & 43 & $(8.6)$ & 17 & 39.5 & \\
\hline $70+$ & 25 & (5.0) & 19 & 76.0 & \\
\hline Sex & & & & & $\chi^{2}=0.81, \mathrm{df}=1, \mathrm{NS}$ \\
\hline Female & 167 & $(33.4)$ & 103 & 61.7 & \\
\hline Male & 333 & $(66.6)$ & 219 & 65.8 & \\
\hline $\begin{array}{l}\text { Education } \\
\quad \text { Illiterate/read and }\end{array}$ & & & & & $\chi^{2}=38.5, \mathrm{df}=3, P<0.001$ \\
\hline write & 196 & $(39.2)$ & 105 & 53.6 & \\
\hline Primary/ & & & & & \\
\hline intermediate & 137 & $(27.4)$ & 79 & 57.7 & \\
\hline Secondary & 112 & $(22.4)$ & 89 & 79.5 & \\
\hline University/higher & 55 & $(11.0)$ & 49 & 89.1 & \\
\hline Occupation (male) & & & & & $\chi^{2}=9.09, \mathrm{df}=5, \mathrm{NS}$ \\
\hline Official worker & 43 & (8.6) & 36 & 83.7 & \\
\hline Student & 22 & (4.4) & 16 & 72.7 & \\
\hline Factory worker & 16 & (3.2) & 9 & 56.3 & \\
\hline Farmer & 61 & $(12.2)$ & 39 & 63.9 & \\
\hline Unskilled worker & 159 & $(31.8)$ & 97 & 61.0 & \\
\hline Unemployed & 32 & $(6.4)$ & 22 & 68.8 & \\
\hline Occupation (female) & & & & & $\chi^{2}=8.43, \mathrm{df}=1, P=0.004$ \\
\hline Housewife & 146 & $(87.4)$ & 84 & 57.5 & \\
\hline Employed & 21 & (12.6) & 19 & 90.4 & \\
\hline Residence & & & & & $\chi^{2}=0.15, \mathrm{df}=1, \mathrm{NS}$ \\
\hline Rural & 191 & $(38.2)$ & 121 & 63.4 & \\
\hline Urban & 309 & $(61.8)$ & 201 & 65.0 & \\
\hline $\begin{array}{l}\text { Crowding index (no. } \\
\text { persons per room) }\end{array}$ & & & & & $\chi^{2}=14.5 \mathrm{df}=2, P<0.001$ \\
\hline$<3$ & 160 & $(32.0)$ & 120 & 75.0 & \\
\hline $3-5$ & 191 & $(38.2)$ & 121 & 63.4 & \\
\hline $5+$ & 149 & $(29.8)$ & 81 & 54.4 & \\
\hline Distance from PHC & & & & & $\chi^{2}=1.23, \mathrm{df}=2, \mathrm{NS}$ \\
\hline$<2 \mathrm{~km}$ & 396 & $(79.2)$ & 252 & 63.6 & \\
\hline$\geq 2 \mathrm{~km}$ & 87 & $(17.4)$ & 57 & 65.5 & \\
\hline Other & 17 & $(3.4)$ & 13 & 76.5 & \\
\hline
\end{tabular}


Table 1 Sociodemographic and health characteristics of all tuberculosis (TB) patients and the 322 with good knowledge scores about the disease (concluded)

\begin{tabular}{|c|c|c|c|c|c|}
\hline $\begin{array}{l}\text { Demographicl } \\
\text { health variable }\end{array}$ & $\begin{array}{r}\text { Total } \\
(\boldsymbol{n}= \\
\text { No. }\end{array}$ & $\begin{array}{l}\text { ample } \\
500) \\
(\%)\end{array}$ & $\begin{array}{c}\text { G } \\
\text { knon } \\
\text { No. }\end{array}$ & $\begin{array}{l}\text { ood } \\
\text { lledge } \\
\% \text { of } \\
\text { total }\end{array}$ & Significance \\
\hline Travel to $P H C$ & & & & & $\chi^{2}=12.4, \mathrm{df}=4, P<0.02$ \\
\hline By foot & 388 & $(77.6)$ & 258 & 66.5 & \\
\hline By bus & 42 & (8.4) & 17 & 40.5 & \\
\hline By car & 62 & $(12.4)$ & 41 & 66.1 & \\
\hline $\begin{array}{l}\text { Stays overnight } \\
\text { with relative } \\
\text { Other }\end{array}$ & $\begin{array}{l}6 \\
2\end{array}$ & $\begin{array}{l}(1.2) \\
(0.4)\end{array}$ & $\begin{array}{l}5 \\
1\end{array}$ & $\begin{array}{l}83.3 \\
50.0\end{array}$ & \\
\hline Smoking status & & & & & $\chi^{2}=0.20, \mathrm{df}=2, \mathrm{NS}$ \\
\hline Smoker & 114 & $(22.8)$ & 73 & 64.0 & \\
\hline Ex-smoker & 46 & $(9.2)$ & 31 & 67.4 & \\
\hline Never smoked & 340 & $(68.0)$ & 218 & 64.1 & \\
\hline Sputum status & & & & & $\chi^{2}=4.09, \mathrm{df}=1, P<0.05$ \\
\hline Smear negative & 94 & $(18.8)$ & 69 & 73.4 & \\
\hline Smear positive & 406 & (81.2) & 253 & 62.3 & \\
\hline$X$-ray status ${ }^{a}$ & & & & & $\chi^{2}=1.92, \mathrm{df}=3, \mathrm{NS}$ \\
\hline Advanced & 109 & $(21.8)$ & 74 & 67.9 & \\
\hline Moderate & 237 & $(47.4)$ & 153 & 64.6 & \\
\hline Minimal & 75 & $(15.0)$ & 49 & 65.3 & \\
\hline Not available & 79 & (15.8) & 46 & 58.2 & \\
\hline
\end{tabular}

resistance when they interrupt their treatment.

\section{Attitudes and practices}

In studying the attitudes and practices of TB patients at the onset of symptoms, $54.8 \%$ were reluctant to seek care for fear of being diagnosed with TB, and $32.8 \%$ because of their poor economic status. Only 5.8\% admited to ignorance or not being worried about their health condition. Reasons for delay were not significantly associated with knowledge. A high proportion of patients (20.6\%) sought initial care at traditional healers, but $67.2 \%$ and $65.2 \%$ sought care at governmental and private health facilities respectively. Again, knowledge had no significant association with care-seeking behaviour.

Almost all patients (94.0\%) did not buy anti-TB medicines from private pharmacies, though this was not significantly associated with good knowledge (64.7\%). Only $43.6 \%$ of patients reported that they encouraged their household members to have TB investigations, and this attitude was significantly associated with good knowledge $(91.3 \%)(P<0.0001)$. For

المجلة الصحية لشرق المتوسط، منظمة الصحة العالمية، المجلد التاسع، العدد ع، بr.ب 


\begin{tabular}{|c|c|c|c|c|c|}
\hline \multirow{2}{*}{$\begin{array}{l}\text { Symptom } \\
\text { Cough }\end{array}$} & \multicolumn{2}{|c|}{$\begin{array}{l}\text { Total sample } \\
(n=500)\end{array}$} & \multicolumn{2}{|c|}{$\begin{array}{c}\text { Good } \\
\text { knowledge }\end{array}$} & Significance \\
\hline & 419 & $(83.8)$ & 281 & 67.1 & $\chi^{2}=8.00, \mathrm{df}=1, P=0.005$ \\
\hline Fever & 283 & $(56.6)$ & 197 & 69.6 & $\chi^{2}=7.72, \mathrm{df}=1, P=0.005$ \\
\hline Chest pain & 222 & $(44.4)$ & 142 & 64.0 & $\chi^{2}=0.03, \mathrm{df}=1, \mathrm{NS}$ \\
\hline Weight loss & 166 & $(33.2)$ & 114 & 68.7 & $\chi^{2}=1.98, \mathrm{df}=1, \mathrm{NS}$ \\
\hline Haemoptysis & 151 & $(30.2)$ & 119 & 78.8 & $\chi^{2}=19.6, \mathrm{df}=1, P<0.001$ \\
\hline Pallor & 113 & $(22.6)$ & 74 & 65.5 & $\chi^{2}=0.08, \mathrm{df}=1, \mathrm{NS}$ \\
\hline \multicolumn{6}{|l|}{ Others } \\
\hline Weakness & 1 & $(0.2)$ & 1 & 100 & \\
\hline Vomiting & 1 & $(0.2)$ & 1 & 100 & \\
\hline Headache & 1 & $(0.2)$ & 1 & 100 & \\
\hline
\end{tabular}

$N S=$ not significant .

$d f=$ degrees of freedom.

71.4\% of patients the physician was the first to suspect TB and for $10.8 \%$ it was a family member (Table 4), but this was not associated with knowledge.

\section{Health care workers}

Overall, 492 out of 500 health care workers (98.4\%) had 'good' scores for knowledge about TB.

\section{Sociodemographic characteristics}

The sociodemographic characteristics of the health care workers surveyed are shown in Table 5. Knowledge about TB was significantly higher among those aged $\geq 30$ years compared with younger respondents $(P<0.001)$ and among those residing in urban areas $(P>0.05)$. Women recorded slightly lower rates of good knowledge compared with men (96.4\% versus $99.0 \%$ ), but this was not statistically significant. The duration of their job ranged from 1 year to 31 years, with more than half of them (52.6\%) recording job durations of
10 to 20 years. There was a significant association between longer job duration and knowledge about the disease $(P=0.03)$. There was a significant association between knowledge of health care workers and higher qualifications $(P=0.02)$.

\section{Knowledge}

Table 6 shows health care workers' knowledge about TB. Almost all (97.5\%) answered that TB affects the lungs, while effects on the bones, kidneys and abdomen, were reported by $66.8 \%, 55.6 \%$, and $50.4 \%$ respectively. Not all health care workers $(87.4 \%)$ knew that TB is caused by a bacterium.

The mode of TB transmission was answered correctly (via the respiratory tract) by $491(98.2 \%)$ of respondents. Almost all health workers $(93.0 \%)$ knew that TB is a health problem in Iraq and $83.6 \%$ said that the main risk factor for TB infection is the continuous close contact with an infected 


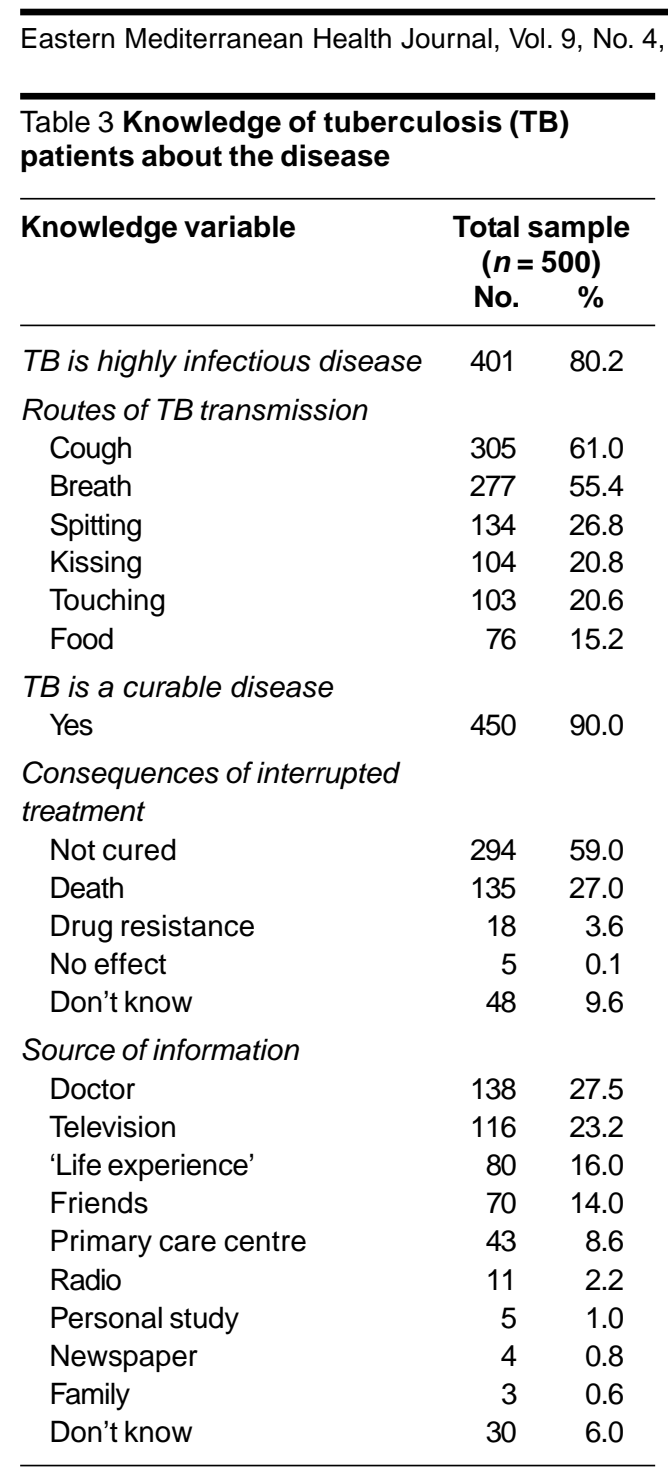

$\mathrm{n}=$ total number of patients interviewed.

person, while $80.8 \%, 68.4 \%$ and $67.8 \%$ mentioned overcrowding, humidity and under-nutrition, respectively, as risk factors for TB infection. The majority (98.2\%) of the studied health care workers mentioned that active pulmonary TB is the most infectious type. Only $1.4 \%$ of the health care workers thought TB of other organs was a major source of infection, while $0.4 \%$ believed that contaminated food was a major source of infection.

Regarding their knowledge about identification of TB, Table 6 shows that $93.2 \%$ of health care workers mentioned that the presence of cough for more than 3 weeks should be one of the identifying criteria; $71 \%$ of the health care workers also mentioned haemoptysis. Moreover $70.0 \%$, $59.8 \%, 58.6 \%, 56.8 \%$ and $51.4 \%$ mentioned night sweats, loss of appetite, chest pain, loss of weight and general weakness respectively. To assess knowledge about the definition of active pulmonary TB, $78.8 \%$ defined active pulmonary TB correctly according to the national guidelines (patient with 2 or 3 direct sputum-positive smears), while $19 \%$ believed that active pulmonary TB could be detected only by chest X-ray.

Correct knowledge about the definition of a case relapse (patient cured returning with smear-positive sputum) was shown by $77.6 \%$ of health care workers. As for the duration of anti-TB treatment for patients with newly diagnosed active pulmonary TB, $87.0 \%$ answered correctly (6-month course) while $6.6 \%$ and $4.4 \%$ gave durations of 9 and $2-3$ months respectively.

\section{Attitudes and practices}

Table 7 shows the attitudes and practices of health care workers and the association with good knowledge scores. Regarding the investigation of household contacts, $90.2 \%$ provided correct answers, and this was significantly associated with good knowledge $(P<0.0001)$. Only $38.2 \%$ of health workers correctly ask for 3 consecutive sputum tests but they had very high rates of good knowledge (99.5\%). A total of $76.4 \%$ health care workers refer TB suspects to specialists and $5.4 \%$ prescribe anti-TB drugs themselves. As for the fre-

المجلة الصحية لشرق المتوسط، منظمة الصحة العالمية، المجلد التاسع، العدد ع، ب... 
Table 4 Attitudes and practices of all tuberculosis (TB) patients and the 322 with good knowledge scores

\begin{tabular}{|c|c|c|c|c|c|}
\hline \multirow[t]{2}{*}{$\begin{array}{l}\text { Attitudes and practices } \\
\text { variable }\end{array}$} & \multicolumn{2}{|c|}{$\begin{array}{l}\text { Total sample } \\
\quad(n=500)\end{array}$} & \multicolumn{2}{|c|}{$\begin{array}{c}\text { Good } \\
\text { knowledge }\end{array}$} & \multirow[t]{2}{*}{ Significance } \\
\hline & No. & $(\%)$ & No. & $\begin{array}{c}\% \\
\text { of total }\end{array}$ & \\
\hline \multicolumn{6}{|l|}{ Reason for delay in visiting } \\
\hline PHC & & & & & $\chi^{2}=9.93, \mathrm{df}=8, \mathrm{NS}$ \\
\hline Fear of diagnosis & 274 & $(54.8)$ & 177 & 64.6 & \\
\hline Economic & 164 & (32.8) & 111 & 67.7 & \\
\hline Not worried & 29 & $(5.8)$ & 16 & 55.2 & \\
\hline Loss of job & 13 & $(2.2)$ & 6 & 54.5 & \\
\hline Too far & 7 & $(1.4)$ & 1 & 33.3 & \\
\hline No family agreement & 3 & $(0.6)$ & 1 & 33.3 & \\
\hline Don't know & 10 & $(2.0)$ & 4 & 40.0 & \\
\hline \multicolumn{6}{|l|}{ Where advice first sought } \\
\hline Government clinic & 336 & $(67.2)$ & 223 & 66.4 & $\chi^{2}=1.73, \mathrm{df}=1, \mathrm{NS}$ \\
\hline Private clinic & 326 & $(65.2)$ & 216 & 66.3 & $\chi^{2}=1.41, \mathrm{df}=1, \mathrm{NS}$ \\
\hline Healer & 103 & $(20.6)$ & 59 & 57.3 & $\chi^{2}=2.87, d f=1, N S$ \\
\hline \multicolumn{6}{|l|}{ Buys anti-TB medicine from } \\
\hline private pharmacy & & & & & $\chi^{2}=0.03, \mathrm{df}=1, \mathrm{NS}$ \\
\hline No & 470 & $(94.0)$ & 304 & 64.7 & \\
\hline \multicolumn{6}{|l|}{ Encourages testing for } \\
\hline $\begin{array}{l}\text { family members } \\
\text { Yes }\end{array}$ & 219 & $(43.6)$ & 200 & 91.3 & $3.2, \mathrm{df}=1, P<C$ \\
\hline \multicolumn{6}{|l|}{ Person who first suspected } \\
\hline$T B$ & & & & & $\chi^{2}=8.93, \mathrm{df}=6, \mathrm{NS}$ \\
\hline Doctor & 357 & $(71.4)$ & 222 & 62.2 & \\
\hline Family & 54 & $(10.8)$ & 43 & 79.6 & \\
\hline Self & 35 & $(7.0)$ & 26 & 74.3 & \\
\hline Health care worker & 33 & $(6.6)$ & 19 & 57.6 & \\
\hline Friend & 14 & $(2.8)$ & 8 & 57.1 & \\
\hline Neighbour & 5 & $(1.0)$ & 3 & 60.0 & \\
\hline Healer & 2 & $(0.4)$ & 1 & 50.0 & \\
\hline
\end{tabular}

PHC = primary health centre.

$N S=$ not significant .

$d f=$ degrees of freedom.

$\mathrm{n}=$ total number of patients interviewed

quency of supervision during the intensive phase (first 2 months) of anti-TB medication, $87.0 \%$ correctly reported that they carry out daily supervision and $99.5 \%$ of this group had good knowledge $(P<$ $0.0001)$.

\section{Discussion}

Using a questionnaire based on the Iraqi national TB programme guidelines for teaching TB patients, almost two-thirds 


\begin{tabular}{|c|c|c|c|c|c|}
\hline \multicolumn{6}{|c|}{$\begin{array}{l}\text { Table } 5 \text { Sociodemographic characteristics of all health care workers and the } 492 \\
\text { with good knowledge scores about tuberculosis (TB) }\end{array}$} \\
\hline \multirow[t]{2}{*}{ Demographic variable } & \multicolumn{2}{|c|}{$\begin{array}{l}\text { Total sample } \\
\quad(n=500)\end{array}$} & \multicolumn{2}{|c|}{$\begin{array}{l}\text { Good } \\
\text { knowledge }\end{array}$} & \multirow[t]{2}{*}{ Significance } \\
\hline & No. & (\%) & No. & $\begin{array}{l}\% \\
\text { f total }\end{array}$ & \\
\hline Age (years) & & & & & $\chi^{2}=10.5, \mathrm{df}=1, P<0.001$ \\
\hline$<30$ & 111 & $(22.2)$ & 106 & 95.5 & \\
\hline $30+$ & 389 & $(77.8)$ & 386 & 99.2 & \\
\hline Sex & & & & & $\chi^{2}=3.71, \mathrm{df}=1, \mathrm{NS}$ \\
\hline Female & 110 & $(22.0)$ & 106 & 96.4 & \\
\hline Male & 390 & $(78.0)$ & 386 & 99.0 & \\
\hline Residence & & & & & $\chi^{2}=0.15, \mathrm{df}=1, \mathrm{NS}$ \\
\hline Rural & 191 & $(38.2)$ & 188 & 98.4 & \\
\hline Urban & 309 & $(61.8)$ & 304 & 98.4 & \\
\hline Qualifications (diploma) & & & & & $\chi^{2}=8.22, \mathrm{df}=2, P=0.02$ \\
\hline Primary nursing & 8 & $(1.6)$ & 7 & 87.5 & \\
\hline Secondary nursing & 53 & $(10.6)$ & 51 & 96.2 & \\
\hline Health institute & 439 & $(87.8)$ & 434 & 98.9 & \\
\hline Duration of job (years) & & & & & $\chi^{2}=5.20, \mathrm{df}=1, P=0.03$ \\
\hline$<10$ & 135 & $(27.0)$ & 130 & 96.3 & \\
\hline $10+$ & 365 & $(73.0)$ & 362 & 99.2 & \\
\hline
\end{tabular}

$N S=$ not significant .

$d f=$ degrees of freedom .

$\mathrm{n}=$ total number of health care workers interviewed.

(64.4\%) of patients recorded good knowledge about TB. Interestingly, there was no significant difference between patients living in rural or urban areas or between males and females regarding their knowledge about TB.

Our study reported that $90.0 \%$ of the patients knew that TB is a curable disease, and $80.2 \%$ that it is highly infectious. In this regard, patients' knowledge was better than that reported from the Serbian province of Kosovo, in spite of health education provided for patients admitted in that programme [13]. It was also better than rates reported from Mwanza, Tanzania, where only $30 \%$ of TB patients recorded satisfactory knowledge about the disease and its treatment [14]. However, these variations between countries regarding the rates of good knowledge could be attributed to different methodologies adopted by the different studies. On the other hand, the studies were in agreement regarding the lack of association between knowledge and area of residence and sex.

The relatively high level of good knowledge reported in this study can probably be attributed to the high level of educational activities carried out by the national TB programme through mass media (television, radio, newspapers) and face-to-face health education. These activities emphasized the seriousness of TB, mode of transmission, the sequelae of treatment interruption, and curability of TB. By contrast, women working as housewives re-

المجلة الصحية لشرق المتوسط، منظمة الصحة العالمية، المجلد التاسع، العدد ع، بr.ب 


\begin{tabular}{|c|c|c|}
\hline \multirow{2}{*}{$\begin{array}{l}\text { Knowledge variable } \\
\text { Organs affected by TB }\end{array}$} & \multicolumn{2}{|c|}{$\begin{array}{c}\text { Total sample } \\
\quad(n=500)\end{array}$} \\
\hline & \\
\hline Lung & 488 & 97.5 \\
\hline Bones & 334 & 66.8 \\
\hline Kidney & 278 & 55.6 \\
\hline Uterus & 270 & 54.0 \\
\hline Abdomen & 252 & 50.4 \\
\hline \multicolumn{3}{|l|}{ Cause of TB } \\
\hline Bacterium & 437 & 87.4 \\
\hline \multicolumn{3}{|l|}{$T B$ is a problem in Iraq } \\
\hline Yes & 465 & 93.0 \\
\hline \multicolumn{3}{|l|}{ Route of TB transmission } \\
\hline Breath & 491 & 98.2 \\
\hline Others & 9 & 1.8 \\
\hline \multicolumn{3}{|c|}{ Factors relevant to TB infection } \\
\hline Household contacts & 418 & 83.6 \\
\hline Overcrowding & 404 & 80.8 \\
\hline Humidity & 342 & 68.4 \\
\hline Under-nutrition & 339 & 67.8 \\
\hline \multicolumn{3}{|c|}{ High infection source for TB } \\
\hline Active pulmonary TB & 491 & 98.2 \\
\hline TB in other organs & 7 & 1.4 \\
\hline Contaminated food & 2 & 0.4 \\
\hline \multicolumn{3}{|l|}{ Signs suspicious for TB } \\
\hline Cough $>3$ week & 466 & 93.2 \\
\hline Fever & 380 & 76.0 \\
\hline Haemoptysis & 355 & 71.0 \\
\hline Night sweats & 350 & 70.0 \\
\hline Loss of appetite & 299 & 59.8 \\
\hline Chest pain & 293 & 58.6 \\
\hline Loss of weight & 284 & 56.8 \\
\hline General weakness & 257 & 51.4 \\
\hline
\end{tabular}

corded low rates of good knowledge. This could be explained by their high illiteracy rates.

Regarding the source of information about TB, 27.5\% gained information from their physicians and $23.2 \%$ from the mass

\begin{tabular}{lrr}
\hline Knowledge variable & \multicolumn{2}{c}{ Total sample } \\
& \multicolumn{2}{c}{$(\boldsymbol{n}=\mathbf{5 0 0 )}$} \\
& No. & $\%$ \\
\hline Definition of active & & \\
pulmonary TB & & \\
$\quad$ or 3 +ve smears & 394 & 78.8 \\
1 +ve smear and +ve X-ray & 133 & 26.6 \\
$\quad$ Only chest +ve X-ray & 95 & 19.0 \\
Definition of TB relapse patients & & \\
$\quad$ Completed treatment, cured & & \\
and returned with +ve smear & 388 & 77.6 \\
$\quad$ Under treatment, sputum & & \\
remained +ve after 5 months & 87 & 17.4 \\
$\quad$ Interrupted treatment for 3 & & \\
$\quad$ months, returned with +ve smear & 73 & 14.6 \\
Duration of treatment of new & & \\
active pulmonary TB & & \\
$\quad$ m months & 435 & 87.0 \\
9 months & 33 & 6.6 \\
2-5 months & 22 & 4.4 \\
Don't know & 10 & 2.0 \\
\hline
\end{tabular}

$\mathrm{n}=$ total number of health care workers interviewed.

media, mainly the television. This finding indicates the need to strengthen health education activities through various mass media and to foster collaboration between physicians working in public health centres and those working in the private sector.

In spite of these high levels of knowledge about TB, more than half of our patients did not have the appropriate health-seeking behaviour in terms of timely access to appropriate care, thereby reflecting a high degree of stigma attached to the disease. This finding is in agreement with other studies reporting that knowledge alone is not the only factor determining the health-seeking behaviour of patients or their adherence to treatment, but mainly the patient's attitudes and practices $[13,15-$ 


\begin{tabular}{|c|c|c|c|c|c|}
\hline \multicolumn{6}{|c|}{$\begin{array}{l}\text { Table } 7 \text { Attitudes and practices of all studied health workers and the } 492 \text { with good } \\
\text { knowledge scores about tuberculosis (TB) }\end{array}$} \\
\hline $\begin{array}{l}\text { Attitudes and practices } \\
\text { variable }\end{array}$ & $\begin{array}{r}\text { Total } \\
(n= \\
\text { No. }\end{array}$ & $\begin{array}{l}\text { ample } \\
00) \\
(\%)\end{array}$ & $\begin{array}{l}\text { C } \\
\text { kno } \\
\text { No. }\end{array}$ & $\begin{array}{l}\text { od } \\
\text { ledge } \\
\% \text { of } \\
\text { total }\end{array}$ & Significance \\
\hline \multicolumn{6}{|l|}{ Would trace patient's contacts } \\
\hline Yes & 451 & $(90.2)$ & 447 & 99.1 & $\chi^{2}=28.0, \mathrm{df}=2, P<0.0001$ \\
\hline \multicolumn{6}{|l|}{$\begin{array}{l}\text { Action taken with suspected } \\
\text { TB patient }\end{array}$} \\
\hline $\begin{array}{l}\text { Ask for } 3 \text { direct smear tests } \\
\text { Refer patient to doctor } \\
\text { Give patient medication }\end{array}$ & $\begin{array}{r}191 \\
382 \\
27\end{array}$ & $\begin{array}{r}(38.2) \\
(76.4) \\
(5.4)\end{array}$ & $\begin{array}{r}190 \\
377 \\
26\end{array}$ & $\begin{array}{l}99.5 \\
98.7 \\
96.3\end{array}$ & $\begin{array}{l}\chi^{2}=2.28, \mathrm{df}=1, \mathrm{NS} \\
\chi^{2}=0.87, \mathrm{df}=1, \mathrm{NS} \\
\chi^{2}=0.80, \mathrm{df}=1, \mathrm{NS}\end{array}$ \\
\hline $\begin{array}{l}\text { Duration of daily supervision } \\
2 \text { months } \\
3 \text { months }\end{array}$ & $\begin{array}{r}428 \\
40\end{array}$ & $\begin{array}{r}(85.6) \\
(8.0)\end{array}$ & $\begin{array}{r}427 \\
39\end{array}$ & $\begin{array}{l}99.8 \\
97.5\end{array}$ & $\chi^{2}=76.3, \mathrm{df}=3, P<0.0001$ \\
\hline $\begin{array}{l}\text { Frequency of medication during } \\
\text { intensive treatment phase } \\
\text { Daily }\end{array}$ & 435 & $(87.0)$ & 433 & 99.5 & $\chi^{2}=59.9, \mathrm{df}=3, P<0.0001$ \\
\hline
\end{tabular}

NS = not significant .

$d f=$ degrees of freedom.

$\mathrm{n}=$ total number of health care workers interviewed.

17]. In addition to knowledge, a complex range of factors affects actual attitudes and practices of the individual, such as perceived stigma, economic resources, culture, health care accessibility and health perceptions. An intensive media-based education campaign is highly recommended in order to reduce TB-associated stigma in the community. Such educational activities should also target behavioural modification rather than being confined to increasing awareness of the community.

With the introduction of the revised national TB control guidelines and the implementation of the DOTS strategy, more emphasis is being given in many countries to health education and counselling of patients as well as supervision of treatment by face-to-face observation of patients. These activities imply a close contact between health care workers and patients, which has increased several-fold over the preDOTS era [18].

Overall, 98.4\% health care workers had good knowledge about TB. The levels of knowledge recorded by health care workers in our study were higher than those reported from India; however, this could be attributed to different methods adopted in the 2 studies [19]. The majority our health care workers (87.8\%) had a diploma qualification which explains the high rate of good knowledge about TB. Not surprisingly, good knowledge was significantly associated with age and duration of work. More experience and a longer duration of work subjects the health care workers to more intensive training courses and evaluation of their promotion by the specialized supervi-

المجلة الصحية لشرق المتوسط، منظمة الصحة العالمية، المجلد التاسع، العلد ؟، ب...T 
sion systems in place under the national TB programme.

In our study, less than quarter of the health care workers were women. This could be attributed to the local culture where women are less likely to work as health care workers, to work in a hospital or to opt to work with TB patients for fear of infecting their children.

In addition to the good overall knowledge about TB among the health care workers, they also had good knowledge about the mode of transmission of TB (98.2\%) and its etiology and case definition (87.4\% and $78.8 \%$ respectively). Furthermore, $93.2 \%$ and $77.6 \%$ of health workers knew the correct definitions of a TB suspect and TB relapsed case respectively. Most health care workers had good knowledge about the duration of treatment of a new TB case and the need for tracing of TB contacts (87.0\% and $90.2 \%$ respectively). These positive findings could be attributed to the continuous health education, training and rigorous supervision of health care workers by the national TB control programme.

By contrast, practices of health workers were poor; for example, only $38.2 \%$ knew how to investigate a suspected TB case correctly. This discrepancy between the knowledge of the health care workers on the one hand and their practice on the other is most probably attributed to the situation of Iraq during this study in 2002.
For 12 years, Iraq suffered the effects of international sanctions on trade, during which time the country faced shortages of supplies and health services, particularly laboratory facilities. Therefore, health care workers have not had opportunities to put their knowledge into practice in an effective way.

It can be concluded that, despite the difficulties faced in Iraq, the educational and other activities of the national TB control programme have had beneficial effects on the knowledge of TB patients and health care workers. However, the relatively good knowledge of TB patients did not significantly influence their practice or negative stigma associated with the disease. Similarly, the relatively good knowledge of health care workers regarding TB was not reflected in their practices, especially regarding the investigation of TB suspects, a deficiency that would negatively influence case-finding and case-holding. An intensive media-based education campaign is recommended to increase awareness of TB, reduce the associated stigma, and to change practices. Strengthening supervision within the national TB programme, ensuring adherence to the DOTS strategy and fostering collaboration between national TB programme and other health care providers, such as the private sector and nongovernmental organizations, are also recommended.

\section{References}

1. Stop TB annual report. Geneva, World Health Organization, 2002:1 (WHO/ CDS/STB/2002).

2. Global tuberculosis control-surveillance, planning, financing. WHO report 2002. Geneva, World Health Organization, 2002:159-60 (WHO/CDS/TB/2002. 295).
3. Annual TB report 2000 (national tuberculosis control programme). Baghdad, Iraq, Ministry of Health, 2000.

4. Pio A. Tuberculosis handbook. Geneva, World Health Organization, 1998 (WHO/ $\mathrm{TB} / 98.253)$. 
5. Diwan JUK, Honey ND, Ahlberg BM. Staff and patient attitudes to tuberculosis and compliance with treatment: an exploratory study in a district in Vietnam. International journal of tuberculosis and lung disease, 1996, 77:178-83.

6. Barnhoorn F, Adriaanse $H$. In search of factors responsible for noncompliance among tuberculosis patients in Wardha district, India. Social science and medicine, 1992, 34:291-306.

7. Westaway MS. Knowledge and attitudes about tuberculosis of black hospitalized TB patients. Tuberculosis, 1990, 71:559.

8. Corona Aguilera AE et al. Conocimientos, percepciones y prácti-cas de grupos de población res-pecto a la tuberculosis, 1994-1996. [The knowledge, attitudes and practice of population groups with respect to tuberculosis 1994-1996.] Revista cubana de medicina tropical, 2000, 52(2):110-4.

9. Wandwalo ER, Morkve O. Knowledge of disease and treatment among tuberculosis patients in Mwanza, Tanzania. International journal of tuberculosis and lung disease, 2000, 4(11):1041-6.

10. Auer $C$ et al. Health seeking and perceived causes of tuberculosis among patients in Manila, Philippines. Tropical medicine and international health, 2000, 5(9):648-56.

11. Bhat $S$ et al. Knowledge, attitudes and practices of newly diagnosed sputum positive cases of pulmonary tuberculosis. Journal of communicable diseases, 1999, 31(4):247-52.

12. Banerjee $A$ et al. Evaluation of a unified treatment regimen for all new cases of tuberculosis using guardian-based su- pervision. International journal of tuberculosis and lung disease, 2000, 4(4): 333-9.

13. Implementation of a national tuberculosis control program in minority communities. Accomplishments and challenges from Kosovo. New York, Doctors of the World, 2004 (http://www. doctorsoftheworld.org/news/ TB_Study_oct11.pdf, accessed 24 November 2004).

14. Wandwalo ER, Morkve O. Knowledge of disease and treatment among tuberculosis patients in Mwanza, Tanzania. International journal of tuberculosis and lung disease, 2000, 4(11):1041-6.

15. Yamada $S$ et al. Attitudes regarding tuberculosis in immigrants from the Philippines to the United States. Family medicine, 1999, 31(7):477-82.

16. Johansson $\mathrm{E}$ et al. Attitudes to compliance with tuberculosis treatment among women and men in Vietnam. International journal of tuberculosis and lung disease, 1999, 3(10):862-8.

17. Jackson L,Yuan L. Family physicians managing tuberculosis. Qualitative study of overcoming barriers. Canadian family physician, 1997, 43:649-55.

18. Molding T. New responsibilities for health departments and public health nurse in tuberculosis keeping the outpatient on therapy. American journal of public health, 1966, 56:416-27.

19. Singla N, Sharma PP, Jain RC. Awareness about tuberculosis among nurses working in a tuberculosis hospital and in a general hospital in Delhi, India. International journal of tuberculosis and lung disease, 1998, 2(12):1005-10. 